\title{
Pengaruh Lama Penyimpanan terhadap Viabilitas dan pH Semen Babi Landrace yang Diencerkan Menggunakan Bahan Pengencer Sitrat Kuning Telur
}

\author{
Wolfhardus V. Feka ${ }^{\mathrm{a}}$, Agustinus A. Dethan ${ }^{\mathrm{b}}$, dan Veronika Y. Beyleto ${ }^{\mathrm{c}}$ \\ ${ }^{a}$ Fakultas Pertanian, Universitas Timor, Kefamenanu, TTU - NTT, 85613, Indonesia. \\ ${ }^{b}$ Fakultas Pertanian, Universitas Timor, Kefamenanu, TTU - NTT, 85613, Indonesia. \\ ${ }^{c}$ Fakultas Pertanian, Universitas Timor, Kefamenanu, TTU - NTT, 85613, Indonesia.
}

\section{Article Info}

\section{Article history:}

Received 10 April 2016

Received in revised form 25 Mei 2016

Accepted 17 Juni 2016

Keywords:

Babi Landrace

Kuning Telur

Viabilitas Spermatozoa

$\mathrm{pH}$ Semen

\begin{abstract}
Abstrak
Penelitian ini bertujuan untuk mengetahui viabilitas dan derajat keasaman (pH) semen babi Landrace pada pengencer sitrat kuning telur yang disimpan selama $24 \mathrm{jam}$. Semen yang digunakan berupa semen segar dari pejantan babi Landrace berusia 1 tahun 8 bulan. Semen dikoleksi dengan metode manual menggunakan induk buatan. Penelitian ini menggunakan metode eksperiment menggunakan Rancangan Acak Lengkap (RAL) dengan empat perlakuan (60 menit, 120 menit, 180 menit, 240 menit) dan empat ulangan sehingga terdapat 16 unit percobaan. Semen segar dievaluasi makroskopis dan mikroskopis di laboraturium Faperta Universitas Timor. Hasil penelitian menunjukkan bahwa penambahan pengencer sitrat kuning telur dalam semen babi Landrace berpengaruh sangat nyata $(\mathrm{P}<0.01)$ terhadap viabilitas semen babi Landrace dengan presentase R1 60 menit $88.38 \%$, R2 120 menit 52.63\%, R3 180 menit $43.38 \%$, dan R4 240 menit $24.00 \%$. Penambahan pengencer sitrat kuning telur memberikan daya hidup terbaik dengan lama waktu penyimpanan selama 180 menit. Sedangkan untuk derajat keasaman $(\mathrm{pH})$ tidak memberikan pengaruh yang nyata $(\mathrm{P}>0.005)$ dimana nilai rataan $\mathrm{pHnya} \mathrm{R} 160$ menit 5.5, R2 120 menit 5.25, R3 180 menit 5.25 dan R4 20 menit 5.0. (92016 dipublikasikan oleh JAS.
\end{abstract}

\section{Pendahuluan}

Babi merupakan salah satu komoditas ternak penghasil daging yang memiliki potensi besar untuk dikembangkan. Hal ini dikarenakan ternak babi memiliki sifat dan kemampuan yang menguntungkan antara lain pertumbuhan yang cepat, jumlah anak per kelahiran (litter size) yang tinggi. Jenis bangsa babi peliharaan yang umum dikonsumsi di Indonesia adalah Babi Landrace, Babi Duroc, dan babi hasil persilangan lainnya.

Jenis usaha peternakan babi di Timor Tengah Utara (TTU) masih merupakan peternakan rakyat berskala kecil atau skala rumah tangga, dimana upaya peningkatan mutu genetiknya terutama populasi masih kurang. Salah satu upaya yang dilakukan untuk meningkatkan populai dan mutu genetik ternak babi adalah menerapkan program inseminasi buatan (IB).

Pencapaian tujuan program IB tergantung pada beberapa faktor yaitu kualitas semen, ketrampilan inseminator, cara mempertahankan kualitas semen segar setelah ejakulasi dari ternak babi tersebut. Oleh karena itu perlu dilakukan upaya pengenceran agar kualitas semen dapat dipertahankan dalam waktu yang relatif lama. salah satu cara mempertahankan kualitas semen dengan harga yang murah adalah dengan menggunakan bahan pengencer sitrat kuning telur.

Kuning telur mengandung protein dan karbohidrat sebagai sumber energi, dan dapat melindungi spermatozoa dari pengaruh cold shock (kejutan dingin) dan dapat mempertahankan kualiatas spermatozoa. Tetapi sejauh ini pengenceran spermatozoa ternak babi khususnya Landrace di Kabupaten TTU menggunakan sitrat kuning telur belum dipakai dan belum diketahui, oleh karena itu perlu dilakukan penilitian dengan menggunakan bahan pengencer sitrat kuning telur terhadap kualitas sperma Babi Landrace. Berdasarkan uraian di atas maka dilakukan penelitian dengan judul: Pengaruh Lama Penyimpanan Terhadap Viabilitas Dan pH Spermatozoa Babi Landrace Yang Diencerkan Menggunakan Sitrat Kuning Telur, dengan tujuan dari penelitian ini untuk mengetahui viabilitas dan $\mathrm{pH}$ spermatozoa Babi Landrace yang diencerkan menggunakan bahan pengencer sitrat kuning telur dengan lama waktu penyimpanan berbeda.

\section{Metode}

Penelitian ini dilaksanakan di Tunbakun, Kelurahan Kefa Tengah (penampungan semen), dan Laboraturium Fakultas Pertanian Universitas Timor (pengujian kualitas sperma). Penelitian ini berlangsung selama 1 bulan terhitung sejak tanggal 24 Februari sampai 12 Maret 2016. Menggunakan satu ekor ternak Pejantan Babi Landrace dengan umur \pm 1-2 tahun (penghasil semen).

Alat yang digunakan dalam penelitian ini adalah: Pipet tetes, Tabung penampung semen berskala, Kertas tissue, Hand Counter, Mikroskop, Haemocytometer, Gelas objek, Gelas penutup kertas indikator, induk buatan (dummy), buku agenda, alat tulis.

Bahan yang digunakan dalam penelitian ini adalah: Semen cair Babi Landrace, Sitrat kuning telur, Aquades, Larutan eosin, Alkohol dan kertas pH

Penelitian ini menggunakan metode experiment laboratorium menggunakan Rancangan Acak Lengkap (RAL) dengan 4 perlakuan dan 4 ulangan sehingga terdapat 16 unit percobaan

Perlakuan yang dilakukan adalah sebagai berikut:

$\mathrm{R} 1$ : sperma + sitrat kuning telur disimpan selama 1 jam

$\mathrm{R} 2$ : sperma + sitrat kuning telur disimpan selama 2 jam

R3 : sperma + sitrat kuning telur disimpan selama 3 jam

$\mathrm{R} 4$ : sperma + sitrat kuning telur disimpan selama 4 jam

Variabel yang diteliti dalam penelitian ini adalah Viabilitas spermatozoa hidup (\%) dan $\mathrm{pH}$ semen Babi Landrace. Kemudian data yang diperoleh di analisis dengan menggunakan Analisis Sidik Ragam atau Analisis of Varience (ANOVA). Apabila terdapat perbedaan antara perlakuan dilanjutkan dengan uji jarak berganda Duncan (Steel and Torrie, 1993).

\section{Hasil dan Pembahasan}

Data awal evaluasi semen secara makroskopis dan mikroskopis pada penampungan menunjukan bahwa volume semen segar Babi Landrace memenuhi syarat dan layak untuk diencerkan. Hasil ini sesuai hasil penelitian (Knox, 2006) dan (Sumardani, 2007) yaitu 200-250 mL. Data dari hasil pengamatan tersebut dapat dilihat pada Tabel 1.

\begin{tabular}{lll}
\multicolumn{2}{l}{ Tabel } & Evaluasi Semen Secara Makroskopis dan Mikroskopis \\
\hline No & Uraian & Hasil Evaluasi \\
\hline 1 & Volume & $200 \mathrm{ml}$ \\
2 & Bau & Bau khas semen babi \\
3 & Konsistensi & Encer \\
4 & Warna semen & Putih susu \\
5 & Gerakan massa & +++ \\
6 & Gerakan individu & $89.00 \%$ \\
7 & pH & 9 \\
\hline
\end{tabular}

\subsection{Pengaruh Perlakuan terhadap Viabilitas Spermatozoa Babi Landrace}

Viabilitas spermatozoa yang dimaksud adalah kemampuan sperma untuk bertahan hidup selama penyimpanan. Hasil penelitian ini menunjukan bahwa viabilitas spermatozoa yang disimpan dalam waktu berbeda mengalami penurunan yang cukup signifikan yakni pada perlakuan R1: 88.38\%, R2: 52.63 $\%$, R3: $43.88 \%$ dan yang paling terendah adalah perlakuan R4: $24.00 \%$. Data viabilitas spermatozoa Babi Landrace dalam penelitian dapat dilihat pada Tabel 2 .

Tabel 2. Viabilitas Spermatozoa Babi Landrace

\begin{tabular}{|c|c|c|c|c|c|c|}
\hline \multirow{2}{*}{ Perlakuan } & \multicolumn{4}{|c|}{ Ulangan } & \multirow{2}{*}{ Jumlah } & \multirow{2}{*}{ Rataan } \\
\hline & 1 & 2 & 3 & 4 & & \\
\hline R1 & 89 & 87 & 85.5 & 92 & 353.5 & $88.38^{\mathrm{d}}$ \\
\hline $\mathrm{R} 2$ & 55.5 & 52 & 54.5 & 48.5 & 210.5 & $52.63^{c}$ \\
\hline R3 & 49 & 42.5 & 38.5 & 45.5 & 175.5 & $43.88^{b}$ \\
\hline $\mathrm{R} 4$ & 23.5 & 20.5 & 26.5 & 25.5 & 96 & $24.00^{\mathrm{a}}$ \\
\hline Total & & & & & 835.5 & 61.63 \\
\hline
\end{tabular}

Hasil analisis statistik menunjukkan bahwa tardapat perbedaan yang sangat nyata, dimana semen segar Babi Landrace yang diencerkan dalam bahan pengencer sitrat kuning telur dan disimpan dalam waktu yang berbeda memiliki perbedaan kualitas.

Hasil penelitian ini menunjukkan bahwa semakin lama spermatozoa dalam bahan pengencer disimpan yakni 240 menit (R4) telah terjadi penurunan jumlah spermatozoa hidup sebesar $76 \%$ yakni selisih persentase sperma normal/tanpa perlakuan dikurangi nilai rataan (R4) $24.00 \%$. Namun pada perlakuan R4 dengan rataan viabilitas spermatozoa $24.00 \%$ tidak layak lagi untuk digunakan hal ini dikarenakan pada perlakuan R4 dengan rataan $24.00 \%$ berada dibawah persyaratan program IB yaitu masih memenuhi Kriteria standar minimum quality control, oleh karena itu perlu dibatasi penggunaan bahan pengencer sitrat kuning terhadap viabilitas spermatozoa Babi Landrace pada perlakuan R3 dengan rataan viabilitas spermatozoa $43.88 \%$ dengan waktu 180 menit.

Penelitian ini menujukkan bahwa pengencer sitrat kuning telur dapat mempertahankan viabilitas spermatozoa dalam waktu 180 menit selanjutnya di atas waktu tersebut spermatozoa akan mengalami kematian, hal ini dikarenakan telah minimnya sumber energi dalam kuning telur yang telah terpakai. 
3.2 Pengaruh Perlakuan Terhadap pH Semen Babi Landrace Dalam Bahan

\section{Pengencer Sitrat Kuning Telur}

$\mathrm{pH}$ semen mencerminkan aktifitas sperma, yang mana $\mathrm{pH}$ semen yang normal maka motilitas spermatozoa akan semakin baik serta merupakan faktor yang mempengaruhi daya tahan hidup spermatozoa. Hasil evaluasi awal semen menunjukan bahwa $89 \%$ spermatozoa motil, hal ini menggambarkan konsentrasi spermatozoa tinggi yang juga akan berpengaruh pada kondisi asam atau basah pada semen. Rataan $\mathrm{pH}$ semen pada penelitian dapat dilihat pada Tabel 3.

Tabel 3. Rataan pH Spermatozoa Babi Landrace Dari Perlakuan

\begin{tabular}{|c|c|c|c|c|c|c|}
\hline \multirow{2}{*}{ Perlakuan } & \multicolumn{3}{|c|}{ Ulangan } & & \multirow{2}{*}{ Jumlah } & \multirow{2}{*}{ Rataan } \\
\hline & 1 & 2 & 3 & 4 & & \\
\hline R1 & 6 & 5 & 6 & 6 & 23 & $5.5 \mathrm{tn}$ \\
\hline $\mathrm{R} 2$ & 5 & 5 & 6 & 5 & 21 & $5.25 \mathrm{tn}$ \\
\hline R3 & 6 & 5 & 5 & 5 & 21 & $5.25 \mathrm{th}$ \\
\hline $\mathrm{R} 4$ & 5 & 5 & 5 & 5 & 20 & $5.0 \mathrm{tn}$ \\
\hline Total & & & & & 84 & 21 \\
\hline
\end{tabular}

Keterangan: superskrip berbeda menunjukan pengaruh perlakuan tidak berbeda nyata $(\mathrm{p}>0.05)$

Derajat keasaman $(\mathrm{pH})$ semen perlu diukur untuk memastikan bahwa cairan semen hasil penampungan memiliki karakteristik yang normal atau tidak. Derajat keasaman $(\mathrm{pH})$ semen Babi Landrace dalam penelitian ini memiliki kisaran $\mathrm{pH}$ $5.0-6.0$, hasil penelitian terhadap $\mathrm{pH}$ semen masih lebih rendah dari penelitian (Garner and E. S. S Hafez, 2000) yaitu 6,4-7,8, hasil penelitian (Sumardani, 2007) yaitu $7,78 \pm 0,44$. Faktor-faktor tersebut terjadi karena yang mempengaruhi adalah umur, tingkat rangsangan, frekuensi ejakulasi, lingkungan dan kualitas pakan (Feradis, 2010).

Hasil analisis statistik menunjukan pengaruh perlakuan berbeda tidak nyata ( $>0.05$ ) dengan rataan $\mathrm{pH}$ yang diperoleh perlakuan (R1) 60 menit pH5.5 kemudian terjadi perubahan pada setiap perlakuan dengan rataan (R2) 120 menit pH 5.25, (R3) 180 menit pH 5.25 dan (R4) 240 menit pH 5.0.

Hasil penelitian ini menunjukan terjadi peningkatannya $\mathrm{pH}$ semen. Kemungkinan terjadinya peningkatan $\mathrm{pH}$ semen dikarenakan semen disimpan semakin lama sehingga ketersediaan makanan dalam bahan pengercer semakin berkurang dan terjadi penurunan proses metabolisme menyebabkan peningkatan asam laktat dalam jumlah yang besar.

\section{Kesimpulan}

Berdasarkan hasil penelitian dapat disimpulkan bahwa :penyimpanan semen segar babi Landrace dalam pengencer Sitrat Kuning Telur dengan waktu berbeda mempunyai pengaruh yang sangat nyata $(\mathrm{P}<0.01)$, dan dapat mempertahankan Viabilitas spermatozoa babi Landrace dalam waktu 180 menit yakni dalam waktu penyimpanan R3 dengan presentase $43.88 \%$ sebagai persyaratan program IB, sedangkan pengaruh penyimpanan semen segar dalam pengencer sitrat kuning telur terhadap derajat keasaman $(\mathrm{pH})$ tidak berpengaruh nyata $(\mathrm{P}>0.05)$ namun terjadi peningkatan pH dari 5.5 menjadi 5.25 pada (R3) 180 menit.

\section{Daftar Pustaka}

Feradis, 2010. Bioteknologi Reproduksi Pada Ternak. Alfabeta, Bandung.

Garner, D.L., E. S. S Hafez, 2000. Spermatozoa and Seminal Plasma. In: Hafez ESE, and B. Hafez, editor. Reproduction in farm Animals.7th Ed. USA: Williams dan Wilkins.

Knox, R.V., 2006. Semen processing.Extending \& Storage for Artificial Insemination in Swine. Dept Anim. Sci. Univ. Ill.

Steel, R.G.D., Torrie, J.H., 1993. Prinsip dan Prosedur statistika (diterjemahkan dari: Principles and Procedures of Statistic, penerjemah: B. Sumantri). PT. Gramedia, Jakarta.

Sumardani, N.L.G., 2007. Viabilitas dan Fertilitas Spermatozoa dalam Modifikasi bts dan zorlesco dengan Penyimpanan Berbeda dalam Rangkaian Inseminasi Buatan pada Babi. (Tesis). Institut Pertanian Bogor, Bogor. 